
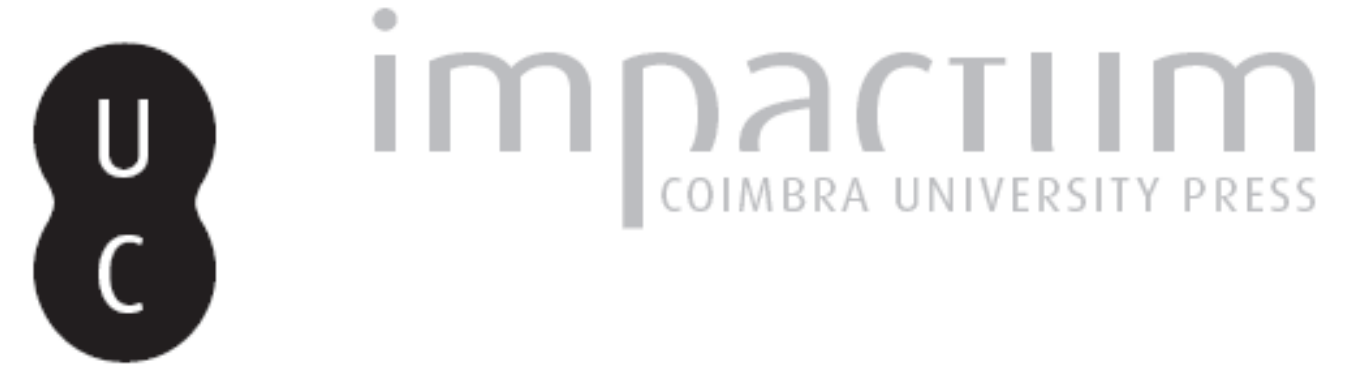

Sobre a determinação do objecto e o escopo da Wissenschaft der Logik de Hegel

Autor(es): $\quad$ Silva, Manuel Moreira da

Publicado por: Faculdade de Letras da Universidade de Coimbra, Instituto de Estudos

Filosóficos

URL

persistente:

URI:http://hdl.handle.net/10316.2/33380

DOI:

DOI:http://dx.doi.org/10.14195/0872-0851_34_2

Accessed : $\quad$ 26-Apr-2023 10:34:25

A navegação consulta e descarregamento dos títulos inseridos nas Bibliotecas Digitais UC Digitalis, UC Pombalina e UC Impactum, pressupõem a aceitação plena e sem reservas dos Termos e Condições de Uso destas Bibliotecas Digitais, disponíveis em https://digitalis.uc.pt/pt-pt/termos.

Conforme exposto nos referidos Termos e Condições de Uso, o descarregamento de títulos de acesso restrito requer uma licença válida de autorização devendo o utilizador aceder ao(s) documento(s) a partir de um endereço de IP da instituição detentora da supramencionada licença.

Ao utilizador é apenas permitido o descarregamento para uso pessoal, pelo que o emprego do(s) título(s) descarregado(s) para outro fim, designadamente comercial, carece de autorização do respetivo autor ou editor da obra.

Na medida em que todas as obras da UC Digitalis se encontram protegidas pelo Código do Direito de Autor e Direitos Conexos e demais legislação aplicável, toda a cópia, parcial ou total, deste documento, nos casos em que é legalmente admitida, deverá conter ou fazer-se acompanhar por este aviso.

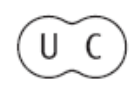




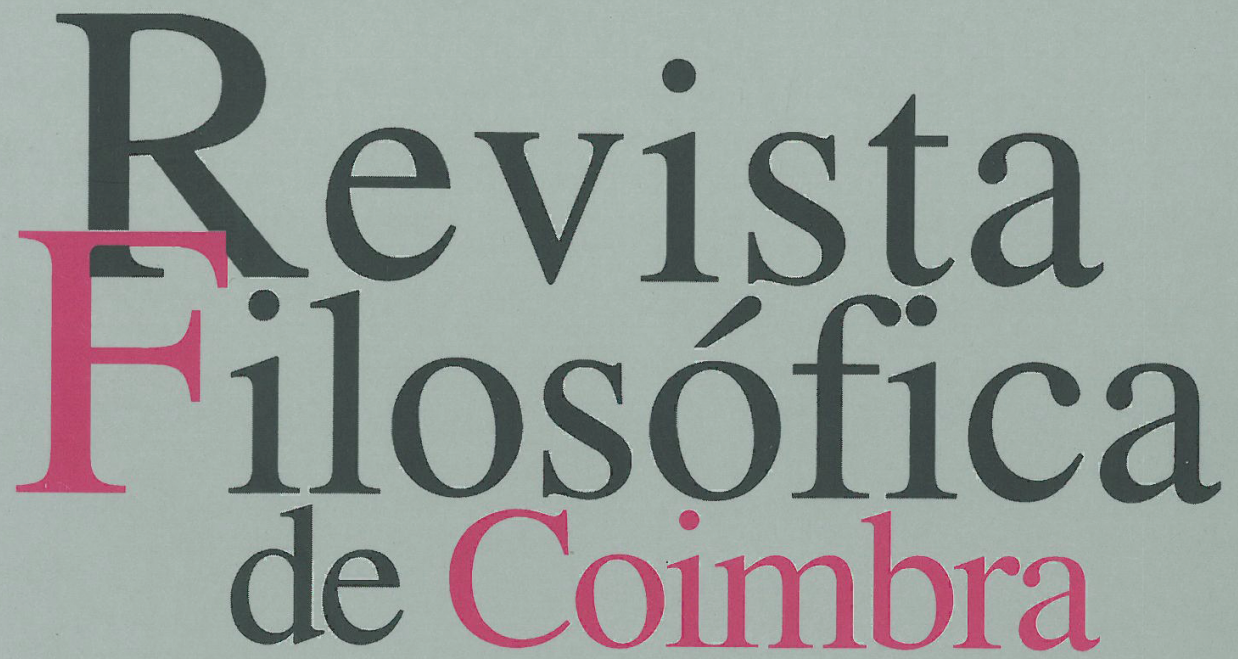

vol.17 | n.34 | 2008

José Reis

Manuel Moreira da Silva Helder Gomes

Filipe P. S. M. Menezes Edmundo Balsemão Maria João Silveirinha Luís António Umbelino Cláudio Alexandre S. Carvalho Armindo dos Santos Ana Isabel Boura Regina Queiroz Dulce Morgado Neves 


\title{
SOBRE A DETERMINAÇÃO DO OBJETO E O ESCOPO DA WISSENSCHAFT DER LOGIK DE HEGEL
}

\author{
MANUEL MOREIRA DA SILVA ${ }^{1}$
}

(Unicentro/PR - Brasil)

Resumo: O artigo propõe-se a uma reconsideração do problema do objeto e o escopo da Wissenschaft der Logik de Hegel no que tange à retomada e desenvolvimento da mesma enquanto Filosofia especulativa pura. Para isso, de um lado, buscar-se-á restabelecer o que, nas Vorlesungen über Logik und Metaphysik de 1817, Hegel designara "o significado mais preciso da Lógica"; de outro lado, em função de tal restabelecimento, esboçar-se-á uma nova configuração dos silogismos da Filosofia, apresentados ao final da primeira (1817) e da terceira (1830) edições da Encyklopädie, de modo a que se possa levar a termo a referida retomada e desenvolvimento. O que, enfim, também poderá mostrar-se como legítima suprassunção das leituras e tomadas de partido acerca da Logik e da própria Logik nos limites de suas realizações literárias.

Palavras-chave: Hegel, Ciência da Lógica, Especulativo puro.

Abstract: This article proposes a reconsideration of the problem of the object and scope of Hegel's Wissenschaft der Logik, with regard to the resumption and development of the same as pure speculative philosophy. For both, on the one hand, will seek to restore what in the Vorlesungen über Logik und Metaphysik, 1817, Hegel appointed "the more precise meaning of Logic"; on the other hand, according to this restoration, outline it to a new configuration of syllogisms of Philosophy, presented the end of the first (1817) and third (1830) editions of Encyklopädie so that it can lead to end the resumption and

${ }^{1}$ Professor do Departamento de Filosofia da Universidade Estadual do Centro-Oeste - UNICENTRO - de Guarapuava, Paraná, Brasil. Secretário de Publicações da Sociedade Hegel Brasileira - SHB - e Editor da Revista Eletrônica Estudos Hegelianos: URL $=<\underline{\text { http:/ }}$ /www.hegelbrasil.org/revista.htm>. 
development. What, finally, can show themselves as legitimate sublation of the readings taken in the party about the Logik and of the Logik itself in the limits of their literary achievements.

Keywords: Hegel, Science of Logic, pure speculative.

\section{Considerações preliminares:}

Desde a publicação de suas primeiras versões, a chamada "Logik Hegels" 2 tem suscitado as mais diversas interpretações e tomadas de partido, sobretudo quanto ao objeto propriamente dito por ela investigado e ao fim essencial da mesma, seu escopo fundamental ${ }^{3}$. O problema é que a diversidade de perspectivas quanto ao tratamento do que constitui em sua essência o objeto e o escopo da Logik parece-nos alimentada pelo próprio Hegel, quem, pelo menos nas Vorlesungen über Logik und Metaphysik, proferidas em 1817, fala explicitamente de no mínimo seis aspectos (ou melhor, determinações) disso que ele denomina " $o$

${ }^{2}$ Fazemos nossa, aqui, em ampliando-a e modificando-a ligeiramente, a concepção inicialmente apresentada por André Doz (1987), segundo a qual a Lógica de Hegel constituise como um objeto ideal (melhor, lógico-efetivo) distinto de suas realizações literárias, históricas e contingentes, nas quais ela se faz presente e assim acessível (fenomênica ou empiricamente) [ver, ANDRÉ DOZ, La Logique de Hegel et les problèmes traditionnels de l'ontologie, Paris: Vrin, 1987, p. 10]. Desse modo, pelo termo 'Logik', bem como pelas expressões que o contêm, utilizadas no mesmo sentido neste trabalho, refiro-me não apenas à Wissenschaft der Logik ou a alguma outra realização da Lógica especulativa em especial, mas à Lógica hegeliana ela mesma no conjunto de suas realizações; quando for o caso, ou o contexto não falar por si mesmo, precisaremos em nota a obra especifica à qual estaremos nos referindo - o mesmo ocorrendo quando o termo utilizado não se referir à Lógica de Hegel, mas sim à Lógica como disciplina ou ciência em geral.

${ }^{3}$ Para algumas das interpretações e tomadas de partido mais importantes do século XX, veja-se FRIEDRIKE SCHICK, Hegels Wissenschaft der Logik - metaphysische Letzbegründung oder Theorie logischer Formen, Freiburg (Breisgau), München: Alber, 1994, p. 13 ss.; para as mais antigas, aparecidas entre 1826 e 1876: D. HENRICH, Anfang und Methode der Logik, in: DIETER HENRICH, Hegel im Kontext, Suhrkamp, 1975, 75-84. Para algumas das quais o próprio Hegel teve acesso, veja-se, de um lado, a interpretação matemática de Pfaff - ainda em 1812 - ao Começo da Wissenschaft der Logik, em: G. W. F. HEGEL, Briefe von und an Hegel, Band I: 1785-1812, Hg. von Johannes Hoffmeister, Berlin: Akademie Verlag, 1970, p. 401-409 [citado de ora avante, em seus três tomos, conforme se segue: Briefe, I, p. 401-409.]; de outro, já em 1929, o segundo artigo da recensão de Hegel - nos Jahrbücher für wissenschaftliche Kritik, 1929, nr. 10-11, 13-14, 37-40, 117-120 - em resposta aos escritos Über die hegelsche Lehre, 
significado mais preciso da Lógica"4. Esses aspectos ou determinações se apresentam ainda nas outras versões da Logik, tanto as anteriores como as posteriores a essas Vorlesungen, ainda que dispersos em vários lugares (à exceção, em parte, daquela contida na Anmerkung ao § 17 da Encyklopädie de 1817) ${ }^{5}$; o que, a nosso ver, juntamente com as dificuldades reconhecidas por Hegel ele mesmo na apresentação do objeto investigado pela Lógica, bem como na realização de seu fim essencial ${ }^{6}$, e, por conseguinte, a perda de integridade estrutural de sua sistematização, contribuiu cabalmente para a proliferação das mais variadas interpretações e tomadas de partido. Quanto a isso, parece-nos que as primeiras objeções importantes - capazes de afetar a integridade estrutural do projeto hegeliano - tenham sido as de Christian Hermann Weisse; no caso, as

oder: absolutes Wissen und moderner Pantheismus (aparecido anonimamente em 1829, mas escrito por um tal Hülsemann) e Über Philosophie überhauipt und Hegels Enzyklopädie der philosophischen Wissenchaften insbesondere (de K. E. Schubart e L. A. Carganico), em G. W. F. HEGEL, Berliner Schriften (1818-1831). Auf der Grundlage der Werke von 1832-1845 neu edierte Ausgabe. Redaktion Eva Moldenhauer und Karl Markus Michel. Frankfurt am Main: Suhrkamp, 1983 [TWA 11], p. 415-636; tradução francesa: Écrits sur la religion (1822-1829). Trad. Jean-Louis Georget et Philippe Grossos, Paris: Vrin, 2001, p. 135-150.

${ }^{4}$ Ver, G. W. F. HEGEL, Vorlesunguen über Logik und Metaphysik(Heidelberg 1817). Mitgeschrieben von F. A. Good. Herausgegeben von Karen Gloy, unter Mitarbeit von Manuel Bachmann, Reinhard Heckmann und Rainer Lambrecht. Hamburg: Felix Meiner, 1992, p. 8. Texto citado de ora avante conforme se segue: VLM, 1817, ad $\S 12$, p. 8 (paginação original da edição crítica). As citações deste texto, bem como de outros que se seguem, salvo indicação especial, são traduzidas por MMDSILVA. Esta obra, bem como suas análogas e os acréscimos à Encykloopädie, será aqui considerada como expressão genuína do pensamento de Hegel e, por isso, utilizada como tal; caso em que me atenho aqui ao axioma clássico: ab esse ad posse valet illatio.

5 Ver, G. W. F. HEGEL, Encyklopädie der philosophischen Wissenschaften im Grundrisse (1817). In: G. W. F. HEGEL, Encyklopädie der philosophischen Wissenschaften im Grundrisse und andere Schriften aus der Heidelberg Zeit, neue herausgegeben von Hermann Glockner, Heidelberg: Frommanns Verlag, 1956, p. 37-38. Texto citado de ora avante conforme se segue: E., 1817, § 17, A. [onde 'A' indica as Anmerkungen - anotações - de Hegel].

${ }^{6}$ Sobre esse ponto, veja-se, G. W. F. HEGEL, Wissenschaft der Logik. Erster Teil: Die objektive Logik. Erster Band: Die Lehre vom Sein (1832), herausgegeben von Friedrich Hogemann und Walter Jaeschke. Hamburg: Felix Meiner, 1985 [GW, Band 21], p. 10. De ora avante, citar-se-á esse texto como segue: WdL, I, 1, 1832, p. 10 (paginação da edição crítica). Seguiremos o mesmo procedimento para as edições de 1812, 1813 e 1816, respectivamente, as doutrinas do Ser, da Essência e do Conceito [GW 11 e GW 12]. 
duas objeções formuladas diretamente a Hegel, em carta de 11 de julho de $1829^{7}$, no que tange à segunda edição da Encyklopädie (1827).

Enquanto dizem respeito à auto-exteriorização da Idéia absoluta na Natureza e o retorno da mesma dentro de si a partir do Espírito, as duas objeções parecem justificar-se sobretudo no fato da subtração do $§ 17$ (em especial de sua anotação) e dos $\S$ 475-477 da Encyklopädie de 1817 na de 1827. A primeira objeção concerne à passagem da Idéia lógica absoluta aos conceitos de espaço e tempo e à natureza; Weisse critica aí o caráter exterior da Natureza em relação à Idéia lógica absoluta, sugerindo que ela teria que ser tanto o aprofundamento quanto o enriquecimento daquela ${ }^{8}$. A segunda objeção diz respeito à conclusão do todo - isto é, à sua restrição ao § 574 na Encyklopädie de1827, sem os silogismos da Filosofia apresentados nos $\S \S 475-477$ na edição de 1817 e nos $\S \S 575$ -577 na de $1830^{9}$-, onde, ao invés da suprassunção de seus momentos anteriores e de seu prosseguimento ascendente, aprofundando-se em si mesmo, no dizer de Weisse, em retornando ao Começo lógico abstrato, o Sistema terminaria por se fechar em si mesmo e, assim, com a admissão de um círculo [vicioso] no qual o que há de mais elevado retornaria ao que é mais pobre, não significaria senão a recusa de toda atividade —, inicialmente pressuposta - e a afirmação de um quietismo absoluto, negando portanto o método mesmo que o anima e que nele se ampliaria ${ }^{10}$. As objeções de Weisse parecem ter atingido o ponto, pois (1) embora na mesma época, junto com as recensões de 192911, Hegel planejasse recensear o comentário de Weisse - também publicado em 1929 - ao seu

${ }^{7}$ Briefe, III, p. 259-263.

8 (Briefe, III, p. 260).

9 Ver, G. W. F. HEGEL, Enciclopédia das Ciências Filosóficas em Compêndio (1830), III. A Filosofia do espírito, trad. Paulo Meneses e Pe. José Machado, São Paulo: Loyola, 1995, p. 363-364. [De ora avante citada (no conjunto de suas três partes) pela inicial 'E', seguida de ' $\S$ ', para os parágrafos correspondentes, e, quando for o caso, de 'A', para a respectiva Anotação (Anmerkung); 'Ad.', refere-se ao adendo (Zusatz) do ì§î em tela]. Se não houver indicações especiais, estaremos utilizando preferencialmente a Enzyklopädie der philosophischen Wissenschaften im Grundrisse (1830), herausgegeben von Wolfgang Bonsiepen und Hans-Christian Lucas. Hamburg: Felix Meiner, 1992 [GW 20]; para os adendos, faremos uso da edição Glockner (do Jubileu) [SW, 8-10], bem como da Moldenhauer/Michel [TWA, 8-10]. No caso: E., 1830, §§ 574-577. Também faremos uso - dos volumes I e III - da Encyklopädie: G. W. F. HEGEL, Encyclopédie des sciences philosophiques. Texte integral présenté, traduit et annoté par B. Bourgeois. Paris: Vrin, 1979 e 1988.

${ }^{10}$ Briefe, III, p. 261.

11 Ver, Jenaer Schriften, op. cit., p. 390, nota 1 (do editor). 
Sistema ${ }^{12}$, o filósofo de Berlim como que aborta este projeto, bem como, ao que parece, jamais responde à carta de Weisse, cujo conteúdo principal era precisamente o desenvolvido na obra não recenseada ${ }^{13}$; (2) apesar disso, justamente na terceira edição da Encyklopädie (1830), como que respondendo à última objeção, Hegel reapresenta os chamados silogismos finais com os quais concluíra a primeira edição da Encyklopädie (1817), agora afirmando de modo expresso a identidade da atividade e do repouso ${ }^{14}$, com isso, reforçando e jogando uma nova luz ao que, na Introdução à Encyklopädie de1830, em seu § 17, se afirmara quanto ao começo que a filosofia tem de instaurar, mostrando agora "que ela parece em geral começar com uma pressuposição subjetiva, como as outras ciências" 15 e não mais que "ela parece em geral fazer a mesma pressuposição subjetiva que esta pela qual começam as outras ciências" ". De onde, agora, adquirir um novo sentido a afirmação segundo a qual "a filosofia se mostra como círculo que retorna dentro de si, que não tem começo no sentido das outras ciências -, de modo que o começo é só uma relação para com o sujeito, enquanto esse quer decidir-se a filosofar, mas não para com a ciência enquanto tal", e ainda, que "o conceito da ciência e por isso o primeiro conceito - e, por ser o primeiro, contém a separação [a saber], que o pensar é o objeto intencional [Gegenstand] para um sujeito filosofante (de certo modo exterior) - deve ser apreendido pela própria ciência", cujo único fim, agir e meta é "alcançar o conceito de seu conceito, e assim seu retorno [dentro de si] e sua satisfação" 17 .

Em vista disso, parece-nos plausível e mesmo necessário que uma investigação em torno do problema da determinação dos limites e o alcance da Logik, de seu objeto investigado e seu escopo, deva consistir antes de tudo na re-sistematização das diversas determinações de seu conceito adequado, bem como na conseqüente suprassunção daquelas determinações nesse conceito. Por isso, nos limitaremos aqui a uma reconsideração de tal problema no que tange à retomada e ao desenvol-

${ }^{12}$ C. H. WEISSE, Über den gegenwärtigen Standpunkt der philosopphischen Wissenschaft, in besonderer Beziehung auf das System Hegels, Leipzig: Joh. Ambr. Barth, 1829.

13 Ver, por exemplo, C. H. WEISSE, op. cit., p. 4 ss., p. 210-212 ss., p. 219 ss.

14 Ver B. BOURGEOIS, Présentation. III. Le développement de l'esprit. In: G. W. F. HEGEL, Encyclopédie des sciences philosophiques, III. Philosophie de l'esprit. Texte integral présenté, traduit et annoté par B. Bourgeois. Première édition. Paris: Vrin, 1988, p. 83-84, nota 34 , iniciada à p. 82 .

15 E., $1830, \S 17$.

${ }^{16}$ E., 1827, § 17 [versão Bourgeois: E., 1827-1830, § 17, nota 1 (Logique, seconde édition. 1979, p. 183)].

17 E., $1830, \S 17$. 
vimento da Logik enquanto Filosofia especulativa pura, segundo a exposição contida na anotação ao § 17 da Encyklopädie de 1817, não mais publicado em 1827 e 1830 , e seu cotejamento com o comentário ao $§ 12$ - da própria Encyklopädie de 1817 - nas Vorlesungen über Logik und Metaphysik desse ano. Neste sentido, de um lado, buscaremos restabelecer o que, nas Vorlesungen über Logik und Metaphysik de 1817, Hegel designara "o significado mais preciso da Lógica"; de outro lado, em função de tal restabelecimento, tentaremos esboçar uma nova configuração dos silogismos da Filosofia, apresentados ao final da primeira (1817) e da terceira (1830) edições da Encyklopädie, de modo a que se possa levar a termo a referida retomada e desenvolvimento. O que, enfim, também poderá mostrar-se como legítima suprassunção das leituras e tomadas de partido acerca da Logik e da própria Logik nos limites de suas realizações literárias.

\section{Sobre o significado mais preciso da Lógica}

Antes de seguir mais adiante, dentre a multiplicidade de aspectos do que Hegel designara "die nähere Bedeutung der Logik"18, há que se estabelecer não o aspecto fundamental de tal Bedeutung mas a Bedeutung mais precisa ela mesma, na qual, de modo necessário, aqueles aspectos ou determinações terão que se fundir. O que deverá nos servir de fio condutor para o confronto com a diversidade de interpretações e tomadas de partido em relação ao System em geral e à Logik Hegels em particular ${ }^{19}$, bem como para a redução de tal diversidade unicamente ao que é conforme ao chamado "ponto de vista especulativo" 20 . Isto, na medida em que este

18 Tradução: "O significado mais preciso da Lógica” (VLM, 1817, ad § 12, p. 6).

19 No âmbito da referida diversidade, mais precisamente nos quadros da filosofia mais recente, destacam-se as seguintes obras: ALEXANDER GRAU, Ein Kreis von Kreisen. Hegels postanalytische Erkenntnisstheorie, Paderborn: Mentis, 2001, p. 15 ss.; PIRMIN STEKELER-WEITHOFER, Hegels analytische Philosophie. Die Wissenschaft der Logik als kritische Theorie der Bedeutung, Padeborn: Schöningh, 1992, XV ss. Veja-se também, VITTORIOHÖSLE, Hegels System. Der Idealismus der Subjektivität und das Problem der Intersubjektivität, 1, Hamburg: Felix Meiner, 1987, p. 12 ss.

20 "Der spekulative Standpunkt". Expressão utilizada pela primeira vez de modo plenamente consciente na Carta a Windischmann, de 23 de agosto de 1823, onde também se afirma que os acessos tradicionais a esse ponto de vista, a saber, a Mística e o Pensamento, "estão agora mais ou menos obstruídos ou inacessíveis pela inundação" (Briefe, III, p. 26-27), mas que - embora ainda de modo insuficiente - já era entrevista por Hegel desde 1812; a saber, enquanto "o ponto de vista superior que o Ser-autoconsciente do Espírito alcançou sobre si”" entre 1787 e 1812 (ver, WdL, I, 1, 1812, p. III). 
designa o próprio Especulativo puro, apresentado por Hegel apenas como "o Racional positivo em geral" 21 , enquanto pensado em sua diferença determinada como a racionalidade positiva oposta à racionalidade dialética; diferença pela qual, não obstante, mantém dentro de si o Negativo enquanto suprassumido $^{22}$, pelo fato de nele Forma (Form) e conteúdo (Inhalt) em geral não serem mais separados. De onde o Especulativo puro ele mesmo estabelecer-se tão só no plano de uma Lógica concebida enquanto "a Filosofia especulativa pura" (die reine spekulative Philosophie).

Concebida enquanto "Filosofia especulativa pura", a Lógica apresenta-se primeiramente (1) como o Absoluto que ainda está contido em sua eternidade, conformando-se assim como Ciência subjetiva e primeira [na qual a Idéia também ainda se contém no Pensar, isso pelo fato de faltar à Lógica, aqui, a perfeita Objetividade da Idéia]. Por conseguinte, trata-se aqui da Subjetividade simples da Inteligência ou do Pensar em si, para nós, ou em geral, mas não já como o Conceito propriamente dito ou livre em si e para si mesmo, isto é, do Conceito livre tanto segundo a forma como segundo o conteúdo ${ }^{23}$. Assim, enquanto o Pensar em si é o "entendimento formalmente idêntico, que elabora as representações rememoradas em gêneros, espécies, leis, forças, etc., em geral em categorias, no sentido que só nessas formas de pensamento a matéria teria a verdade de seu ser" 24 , o Pensar em si e para si ou o Conceito livre ele mesmo é o que "suprassume as determinações-de-forma e põe ao mesmo tempo a identidade das diferenças" 25 , apresentando-se como "o conceito propriamente dito" ou o universal que "é conhecido como se particularizando a si mesmo e retornando-se da particularidade na singularidade", ou, o que é o mesmo, rebaixando o particular a um momento do Conceito, de modo que o universal não seja mais uma forma exterior ao conteúdo, "mas a forma verdadeira, que produz o conteúdo a partir de si mesma"26. De onde, de ora avante, o Pensar não ter "nenhum outro conteúdo que a si mesmo, que suas próprias determinações, as quais constituem o conteúdo imanente da forma" e, portanto, procurando e encontrando no objeto [Objekt] só a si mesmo, estando numa relação perfeitamente livre para com o mesmo ${ }^{27}$.

${ }^{21}$ No original: "Das Spekulative ist das positiv Vernünftige überhaupt" (VLM, 1817, ad $\S 16$, p. 12).

22 VLM, 1817, ad $\S 16$, p. 13.

${ }^{23}$ E., $1830, \S \S 466-467$

${ }^{24}$ E., $1830, \S 467$.

25 E., 1830, § 467.

${ }^{26}$ E., 1830, § 467 Ad.

27 E., 1830, § 467 Ad. 
A Subjetividade simples da Inteligência ou do Pensar em si e o Conceito propriamente dito ou livre em si e para si mesmo constituem respectivamente - o primeiro e o terceiro graus do Pensar puro, sendo o segundo a divisão [Diremtion] ou o juízo que "não mais dissolve o conceito na oposição anterior entre universalidade e ser, mas, segundo os nexos peculiares do conceito, o diferencia" 28 . Tal é, do ponto de vista da própria Lógica ainda concebida como Ciência subjetiva e primeira ${ }^{29}$, o que permite o perfazer-se da própria Objetividade da Idéia; de modo que, em segundo lugar, (2) a Lógica passe para o lado desta perfeita Objetividade como tal, perfazendo-se enquanto Ciência objetiva e universal real [que, assim, assume aquela riqueza do mundo sensível, bem como do mundo concreto ou do mundo intelectual, antes impelida para fora (como sua essência), mas que, agora também se mostra e é reconhecida na Filosofia da parte real (in der Philosophie des realen Theils), retornando à Idéia pura e nesta tendo seu fundamento último e verdade]. Isso, de modo que (3) a universalidade lógica - melhor, a Lógica ela mesma - apresente-se não mais como uma particularidade face à riqueza real, mas contendo-a, mostrando-se como universalidade verdadeira e assim recebendo o significado de Teologia especulativa ${ }^{30}$.

No que tange às indicações do $§ 17$ (em seu caput) da Encyklopädie de 1817, à diferença dos $\S \S 13-16$, Hegel não está a discutir a Forma (Form) do Lógico, mas, sobretudo, o seu conteúdo (Inhalt) ou o que é propriamente lógico-efetivo; portanto, as determinações do Pensar em si e para si mesmas. Contudo, - de acordo com a anotação ao próprio $\S 17$ e o item 7 do comentário ao $\S 12$ e os comentários aos $\S$ 13-17 da mesma, nas Vorlesungen proferidas ainda em 1817, sobretudo porque "o universal como universal simples não tem nenhuma verdade" 31 e o "conteúdo sem forma não se deixa pensar"32 - não sem tomá-las especulativamente, por conseguinte, segundo a sua Forma adequada ou a unidade da Forma e o conteúdo, possível tão só pela Racionalidade positiva ou o procedimento especulativo como tal, pelo qual o Lógico, enquanto o Racional positivo, se desenvolve como em um sistema de graus sempre crescentes. $\mathrm{O}$ que, infelizmente não parece ser o caso nem da chamada grande Lógica - aqui, o conjunto da edição completa de

${ }^{28}$ E., $1830, \S 467$.

${ }^{29}$ E., $1817, \S 17$ A.; E., 1830, § 467, A.

30 E., 1817, § 17, A.

${ }^{31}$ No original: "Das Allgemeine als bloss Allgemeines hat gar keine Wahrheit" (VLM, 1817, ad §13, p. 9).

32 No original: "Inhalt ohne Form lässt sich nicht denken” (VLM, 1817, ad §17, p. 23). 
1812-1816 e a Doutrina do Ser 1832 - nem da pequena Lógica contida na Encyklopädie de 1830, nas quais, apesar de algumas exceções, como ao fim da Doutrina do Conceito $^{33}$ de 1816 e no adendo ao $\S 82$ da Encyklopädie de 1830, o conteúdo do Lógico parece confundir-se com o - ou reduzir-se ao - conteúdo da Lógica enquanto Ciência subjetiva e primeira, no sentido em que, aí, as determinações do Pensar em si e para si mesmas permanecem - apesar disso - tão somente para nós, em si ou em geral ${ }^{34}$, não avançando para além de sua plataforma categorial, tornando-se em si e para-si, em si e para si mesmas, como já o exigia as discussões sobre o verdadeiro, levadas a termo - entre outros lugares -, por exemplo, nos $\S 25$ e 438 da Phänomenologie des Geistes de 180735. Assim, na Encyklopädie de 1830, de modo mais preciso, no adendo ao $\S 83$ dessa versão, Hegel apenas acena ao conteúdo do Lógico, como pressupondo-o no momento especulativo ou positivo racional de sua Forma; com o que os três graus do Pensar ou do Lógico aqui se confundirem com o Ser, a Essência e o Conceito, apresentando-se, respectivamente: (1) como o Conceito em si ou em sua imediatez, (2) o Conceito em sua reflexão e mediação, como posto, enquanto parasi ou em sua aparência e, enfim, (3) em seu ser-retornado sobre si mesmo e ser-junto-a-si-mesmo desenvolvido ou em si e para si. O que impõe um sério problema aos que investigarm o objeto e o escopo da Logik, isto é, do Lógico enquanto seu conteúdo lógico-efetivo em si e para si mesmo - na unidade de seus três momentos formais - como objeto da Lógica ${ }^{36}$, bem como dos limites e o alcance desta enquanto consideração especulativa daquele, do Especulativo puro como a unidade negativa da Forma e o conteúdo do Lógico em si e para si mesmo; de onde, a multiplicidade de interpretações e tomadas de partido em relação à Logik.

${ }^{33} \mathrm{WdL}, \mathrm{II}, 1816$, p. 251.

${ }^{34}$ E., 1830, § 17, § 24 ad 1, § 381 Ad.; WdL, II, 1816, p. 253; WdL, I, 1, 1832, p. $17-18$.

35 G. W. F. HEGEL, Phänomenologie des Geistes (1807), neu hrsg. von Hans-Friedrich Wessels u. Heirinch Clairmont. Mit e. Einleitung von Wolfgang Bonsiepen. Hamburg: Meiner, 1988 , p. 19, p. 288. Para facilitar a leitura dessa obra, além da paginação dessa edição original, lançaremos mão da numeração dos parágrafos utilizada na versão Meneses [Fenomenologia do Espírito, - 2. Ed. - São Paulo: Loyola, 2003]; assim, de ora avante, citaremos a referida obra pelas iniciais ' $\mathrm{PhG}$ ', seguida de '§' e do número dos respectivos parágrafos, e (entre parêntesis) do número da página correspondente na edição original utilizada. De onde, para o caso em questão: $\mathrm{PhG}, \S$ $25, \S 438$ (p. 19, p. 288). 
Não obstante, se levarmos em conta os aspectos do significado mais preciso da Lógica, nos quais, na verdade, Hegel está a se referir ao conteúdo do Lógico, confrontando-os com o que foi dito mais acima, assim como com as diversas interpretações possíveis da Lógica, poderemos não só distinguir adequadamente entre o conteúdo da Logik e o conteúdo do Lógico, mas também precisar sua unidade e, enfim, o objeto e o escopo da Lógica segundo a totalidade em movimento de suas configurações ${ }^{37}$. Para isso, o comentário ao $§ 17$ da Encyklopädie de 1817, nas Vorlesungen über Logik und Metaphysik, mostrar-se-nos-á fundamental, pois é justamente aí onde Hegel distingue de modo mais preciso entre o que é o conteúdo da Lógica e o conteúdo do Lógico: de um lado, o que constitui o conteúdo da Lógica é o sistema das determinações-de-pensamento, no qual as mesmas se apresentam (1) não no sentido de um pensar subjetivo, que consideraria uma determinação-de-pensamento em face de um objeto e reflexão exterior do mesmo ou (2) em sua correção determinada, abstraída de sua determinação-de-pensamento oposta, mas (3) em si e para si, como: (a) conteúdo universal, absoluto; (b) a Forma lógica do conteúdo mesmo e (c) a Forma enquanto conteúdo e o conteúdo como Forma, ambos em sua identidade ou não-separados ${ }^{38}$; de outro lado, por seu turno, o conteúdo do Lógico se apresenta apenas como os distintos

\footnotetext{
${ }^{36}$ E., 1817, § 13, mais A., § 17, mais A.

${ }^{37}$ Pela expressão "totalidade em movimento de suas configurações" entendo aqui o conjunto dos momentos essenciais da Lógica em seu movimento completo e, nela, dos graus do Lógico; melhor, a reunião de seus três momentos (ou suas configurações) fundamentais nos chamados três silogismos da Filosofia, tematizados no final da Encyklopädie em sua primeira e terceira versões publicadas pelo seu próprio autor (ver, E., 1817, §§ 476-478; E., 1830, §§ 575-577), onde o que está em jogo é “o Lógico com a significação que ele é a universalidade verificada no conteúdo concreto" (E., 1817, § 475 ) "como em sua efetividade" (E., 1830, § 574) e, portanto, como: (1) fundamento e ponto de partida primeiro (E., 1817, § 476; E., 1830, § 575), (2) o resultado e o ponto de chegada, onde a Idéia se impõe como fundamento último e verdade (E., 1817, §477; E., 1830, § 576), (3) a razão que se sabe, o absolutamente universal, o meio-termo que se cinde em espírito e natureza, o julgar-se pelo qual a Idéia se reparte em espírito e natureza e os determina como Manifestationen da razão que se sabe e o que se reúne nela, a natureza da Coisa ou o que se move para frente e se desenvolve, "a Idéia eterna e essente em si e para si, que eternamente se ativa, engendra, e desfruta, como espírito absoluto" (E., 1830, §577) ou, o Conceito que se sabe e tem por sua realidade pura e simplesmente os termos que são enquanto momentos do Conceito e é como o Saber universal que, em sua determinidade, permanece imediatamente junto de si mesmo (E., 1817, § 478; E., 1830,§ 577).

38 VLM, 1817, ad § 17, p. 19; E., 1817, § 17 A.
} 
graus de desenvolvimento do mesmo enquanto determinação do pensar em si e para si mesma - exprimindo-se segundo justamente sua configuração silogística - como "o conteúdo universal de tudo" ou o conteúdo próprio da Lógica, a saber: (a) o Universal defronte o Particular, pelos quais a Lógica, como ciência universal, ou ideal, se diferencia das ciências reais, particulares, (b) em si, porém, como o Real absoluto e (c) na Idéia, Real e Ideal, Subjetivo e Objetivo, os quais em sua unidade formam a essência $^{39}$. Há que se precisar, ainda, que neste contexto a essência diz respeito ao próprio Lógico enquanto "der allgemeine Inhalt von allem" 40 , em seu duplo aspecto na Idéia [a Idéia ela mesma como a identidade de ambos os aspectos em sua diferença ou o conteúdo como a Identidade da identidade e da não-identidade], a um tempo Universal e Particular, Ideal e Real, Subjetivo e Objetivo ${ }^{41}$; de onde a essência, aqui, não mais simplesmente aparecer (erscheinen), mas manifestar-se (sich manifestieren), constituindo-se como a necessidade que é "a realidade ou o objeto de conhecimento do Conceito, assim como o Conceito" de que fala a Doutrina do Conceito da grande Lógica ${ }^{42}$ de 1812-1816 ou "a necessidade oculta sob a aparência da contingência" de que fala o adendo ao $\S 145$ da Encyklopädie de $1830^{43}$. Todavia, nas versões da grande Lógica e da pequena Lógica de 1830, como o conteúdo da Lógica e o do Lógico se não se apresentam confundidos as expensas de Hegel, se mostram como tais pelo menos indeterminados; isso porque, a nosso ver, como fica claro no comentário ao $\S 17$ da Encyklopädie de 1817, nas Vorlesungen über Logik und Metaphysik [assim como nas outras versões da Logik e nas Vorlesungen über Logik de 1831], Hegel diz expressamente que "a Lógica não será considerada como Ciência absoluta, mas simplesmente como uma ciência pela qual o Universal será determinado [enquanto] separado do Concreto" 44 , isto é, do próprio Lógico-efetivo de

\footnotetext{
39 VLM, 1817, ad $\S 17$, p. 21.

40 Tradução: "O conteúdo universal de tudo" (VLM, 1817, ad § 17, p. 21.

${ }^{41}$ VLM, 1817, ad § 17, p. 20-21; E., 1817, § 17, A.; E., 1830, § 577.

${ }^{42} \mathrm{WdL}, \mathrm{II}$, p. 230.
}

${ }^{43}$ Sobre esse sentido da necessidade, veja-se: E., 1830, §§ 156-159. Ver também os comentários a esses parágrafos nas Vorlesungen über die Logik, (Berlin 1831, nachgeschrieben von Karl Hegel. Hrsg. von Udo Rameil unter Mitarbeit von Hans-Christian Lucas, Hamburg: Felix Meiner, 2001, aqui, na versão francesa, G. W. F. HEGEL, Leçons sur la logique (1831), présentation de Jean-Marie Lardic, traduction et notes de Jean-Michel Buée et David Wittmann, Paris: Vrin, 2007, p. 158-162. Texto citado de ora avante conforme se segue: VL, 1831, §§ 156-159; quando necessário utilizaremos a paginação da edição alemã.

${ }^{44}$ No original: "Hier aber wird die Logik nicht als absolute Wissenschaft betrachtet, sondern bloss als eine Wissenschaft, wodurch das Allgemeine getrennt von dem Konkreten bestimmt wird" (VLM, 1817, ad § 17, p. 24). 
que falam as anotações ao $\S 13$ da Encyklopädie de 1817 e ao $§ 79$ da de 1830; isso, ainda que ele mesmo reconheça que "o elemento concreto do saber é o espírito" e que este por sua vez "não é nem o Universal nem o Concreto da Lógica, mas é tanto universal quanto concreto, isto é, a Idéia, [a] identidade de ambos" 45 . O que parece significar que, pelo menos em suas realizações literárias efetivamente levadas a cabo, Hegel tratou única e exclusivamente do primeiro aspecto do significado mais preciso da Lógica - a saber, enquanto "ciência do pensar, de suas determinações e leis em geral" 46 - deixando os outros aspectos de lado.

Ao que tudo indica, tendo em vista as Vorlesungen über die Logik, isso ocorre em função de dois procedimentos distintos: primeiro, pelo fato de, segundo Hegel, a Lógica limitar-se unicamente ao tratamento das Formas, no caso, de acordo com as -Vorlesungen de 1817, da Forma lógica do conteúdo, portanto, em sua dependência do conteúdo, para que sejam verdadeiras; segundo, em função do que aí estar em jogo ser a Forma lógica do conteúdo, pelo fato de ser a Forma - enquanto a Idéia ela mesma - que determina o conteúdo, mesmo que esse, como conteúdo verdadeiro, não seja mais que a Forma absoluta, o Conceito ou a Idéia ${ }^{47}$, e, por conseguinte, dela não se distinguir. Em todo caso, isso significa que na Logik assim considerada o conteúdo próprio que se impõe como seu objeto de investigação não é o Lógico propriamente dito ou "o conteúdo universal de tudo", mas tão somente a Forma do conteúdo desse conteúdo, mais especificamente, a identidade da Forma e do conteúdo das determinações-de-pensamento, a "Forma como conteúdo e o conteúdo como Forma" 48 ; o que parece justificar-se, já desde a Doutrina do Ser de 1812 até a de 1832, pelo fato que "o Lógico, no começo do estudo, não está presente para o espírito nesta força consciente" [do que está contido no homem ou do espírito ele mesmo], ainda que isso não impeça o espírito humano de receber dentro de si, por intermédio do próprio Lógico, a força que o conduz à verdade ${ }^{49}$. Assim, considerando que, em geral, as determinações-de-pensamento passam por (durchziehen) nosso espírito de modo instintivo e inconsciente, e mesmo pelo fato delas

${ }^{45}$ No original: "Das konkrete Element des Wissens ist der Geist; er ist weder das allgemeine noch das Konkrete der Logik, aber er ist sowohl Allgemeines als Konkretes, d. h., er ist die Idee, [die] Identität von beiden" (VLM, 1817, ad § 17, p. 24).

${ }^{46}$ E., 1817, § 12; VLM, 1817, ad § 12, p. 8; E., 1830, § 19, §24 ad 1; VL, 1831, § 19, p. 8.

${ }^{47}$ VLM, 1817 , ad $\S 17$, p. $22 ;$ VL, 1831, § 19, p. 8.

48 VLM, 1817, ad $\S 17$, p. 22-24.

49 WdL, I, 1, 1812, p. 29; WdL, I, 1, 1832, p. 42. 
passarem no interior da linguagem ${ }^{50}$, a tarefa precípua da Ciência lógica seria justamente o estudo científico "do pensar, de suas determinações e leis em geral"; pelo que se distingue da chamada Lógica natural - não propriamente pura e racional, mas encontrada meramente no sentimento (Gefühl) da razão -, Lógica natural essa que se limita à figura simplesmente autoconsciente ou à figura exterior do pensar, tematizando apenas o ser-aí deste, segundo sua Forma simples ou seu uso natural e inconsciente consignado na linguagem, sem seguir rigorosamente as regras que ela mesma estabelece na sua Teoria para a Lógica (Theorie für Logik $)^{51}$. De onde, ao contrário, a Lógica científica, além de investigar o ser-aí do Pensar ou sua Forma simples, examinar também o que ele é em si e para si com a significação de sua universalidade ou com o significado que o mesmo é a um tempo subjetivo e objetivo ${ }^{52}$; ou ainda, considerá-lo em sua verdade, no sentido específico que "conceber algo, apreender verdadeiramente algo, significa conhecer o Conceito, a Idéia, o Universal do mesmo" 53 ou que, como"wissenschaftliche Logik, "a Lógica é o saber da Razão de si" 54 , não a simples consciência de ter pensamentos, porém, o uso ou, melhor, a produção consciente não só do ser-aí ou a Forma simples do Pensar ou das determinações-de-pensamento, mas, sobretudo, do próprio Pensar, de sua determinações e leis ou de sua essência pura ${ }^{55}$.

III. O tratamento pedagógico-literário e a reconfiguração do significado essencial da Logik enquanto Filosofia especulativa pura

Em que pese o fato de em suas realizações literárias, a Lógica não ser tomada como Ciência absoluta, mas apenas como uma ciência pela qual o Universal é determinado [enquanto] separado do Concreto ${ }^{56}$, em praticamente todas essas realizações a Wissenschaft der Logik não só exige tal aspecto como também o afirma de modo expresso, ainda que, em alguns casos, sob a figura da metáfora; o que se explica pelo fato mesmo de o conteúdo da Lógica - isto é, o Lógico - e o conteúdo do

${ }^{50}$ WdL, I, 1, 1832, p. 10-11; p. 17-18.

51 VLM, 1817, ad $\S 12$, p. 8.

52 VLM, 1817, ad $\S 12$, p. 6.

53 VLM, 1817, ad $\S 12$, p. 6.

${ }^{54}$ VLM, 1817, ad $\S 12$, p. 6. Veja-se também: E., 1830, § 17, § 24 ad 1, § 381 Ad; WdL, II, 1816, p. 253; WdL, I, 1, 1832, p. 17-18.

55 VL, 1831, § 19, p. 9.

56 VLM, 1817, ad $\S 17$, p. 24. 
Lógico ele mesmo se apresentarem como um só e o mesmo, com a única diferença que, neste seu primeiro aspecto, a Lógica se define pelo Lógico enquanto o Universal defronte do Particular. De onde, por um lado, ela abarcar de modo explícito - no conjunto de suas realizações literárias apenas o Especulativo puro em si ou, o que é o mesmo, limitado à "Racionalidade positiva em geral", por conseguinte, enquanto "ele é pensado em sua diferença determinada" 57 , como "a Idéia no pensar, ou o Absoluto ainda encerrado em sua eternidade" 58 ou "Deus, como ele é em sua essência eterna, antes da criação da natureza e do espírito finito" 59 ; bem como, por outro lado, de modo implícito, as suas outras significações, algumas das quais explicitamente referidas no interior mesmo do desenvolvimento interior da Lógica como Ciência universal, subjetiva ou primeira, mas não desenvolvidas em si e para si mesmas segundo sua autonomia ou em sua esfera própria. Tal é o caso, por exemplo, da Lógica como Ciência objetiva e universal real e, ainda, como Teologia especulativa, aludidas na anotação ao § 17 da Encyklopädie de 1817 e no comentário ao $\S 12$ da mesma nas Vorlesungen de Heidelberg, sobretudo no sentido em que, mediante sua unidade com a Ciência universal, subjetiva e primeira, a Lógica se apresentará, no significado essencial de filosofia especulativa, ocupando assim a posição da Metafísica de outrora, com ela coincidindo ou tomando o seu lugar ${ }^{60}$; essa coincidência, contudo, de um lado, ao ocorrer apenas no âmbito da Lógica objetiva - isto é, das doutrinas do Ser e da Essência - como a primeira parte da Wissenschaft der $\operatorname{Logik}^{61}$ e, de outro, ao deixar a Doutrina do Conceito como que de lado, impõe um novo problema aos que investigam o objeto e o escopo da Logik. Quer dizer, se, de fato, como afirma o prefácio à primeira edição da Wissenschaft der Logik ${ }^{62}$, a Ciência lógica constitui a Metafísica propriamente dita ou a Filosofia especulativa pura, então: ou a primeira - como a Metafísica de outrora - teria que perfazer

${ }^{57}$ No original: "Das Spekulative ist das positive Vernünftige überhaupt, insofern es in seinem bestimmten Unterschied gedacht wird" (VLM, 1817, ad § 17, p. 35).

${ }^{58}$ No contexto original: "Weil aber die Logik als die rein speculative Philosophie, zunächst die Idee im Denken, oder das Absolute noch in seine Ewigkeit eingeschlossen ist" (E., 1817, § 17 A).

59 No original: "Man kann sich deswegen ausdrücken, daß dieser Inhalt die Darstellung Gottes ist, wie er in seinem ewigen Wesen vor der Erschaffung der Natur und des endlichen Geistes ist" (WdL, I, 1, 1832, p. 34).

${ }^{60}$ E., 1817, § 18; E., 1830, § 9, A.; § 24; VL, 1831, § 24, p. 19; WdL, I, 1, 1812, p. 7; WdL, I, 1, 1832, p. 7.

${ }^{61} \mathrm{WdL}, \mathrm{I}, 1,1812$, p. 32; WdL, I, 1, 1832, p. 48-49.

62 WdL, I, 1, 1812, p. 7; WdL, I, 1, 1832, p. 7. 
toda a extensão da segunda, o que se mostra absurdo, pois aquela não possuía ou não considerava o Lógico enquanto Sujeito livre como objeto de investigação; ou a Metafísica aí constituída enquanto Filosofia especulativa pura nada mais teria a ver com a Metafísica tradicional, ainda que a contivesse na primeira parte do primeiro momento da Filosofia especulativa pura, a saber, na Lógica objetiva enquanto primeira parte da Lógica entendida como "ciência do pensar, de suas determinações e leis em geral". $\mathrm{O}$ que, ao que tudo indica, parece estar de acordo com a explicitação do próprio Hegel acerca do conceito da Metafísica, como a "ciência da essência das coisas em geral", na medida em que ela se limita ao Lógico por si, enquanto não se refere às determinações-de-conceito propriamente ditas, mas apenas às determinações-de-pensamento em geral ou enquanto pertencentes ao pensar subjetivo ${ }^{63}$, em todo caso, deixando em aberto ou mesmo deslocando a tematização do Lógico em si e para si, portanto segundo as determinações-de-conceito propriamente ditas, ainda que nos limites da Lógica como "ciência do pensar, de suas determinações e leis em geral", para o âmbito da Lógica subjetiva, a chamada Lógica do Conceito, enquanto a segunda parte da Wissenschaft der Logik ${ }^{64}$.

Essa solução, contudo, apesar de plausível, não resolve adequadamente o problema inicial posto no parágrafo anterior; isto é, o do lugar determinado e da função específica da Lógica segundo o significado de Ciência objetiva e universal real e o de Teologia especulativa, aludidos na anotação ao § 17 da Encyklopädie e no comentário ao § 12 das Vorlesungen de 1817, na sua unidade com o de Ciência universal, subjetiva e primeira, conformando a Lógica no significado essencial de filosofia especulativa; ao contrário, a solução encontrada termina por dissolver completamente os significados de Ciência objetiva e universal real e Teologia especulativa, resumindo a Lógica em Ciência do pensar, de suas determinações e leis em geral e concebendo-a de fato simplesmente como Ciência universal, subjetiva e primeira ${ }^{65}$, fazendo-

${ }^{63}$ No original: "Unter Metaphysik wurde von jeher die Wissenschaft des Wesens der Dinge überhaupt, somit dessen, was sie im reinen Gedanken sind, oder ihre logische Natur verstanden. Sie enthielt dieses Logische teils für sich, insofern es nämlich nicht eigentliche Begriffsbestimmungen betrifft, welche nur als dem subjektiven Denken angehörig angesehen wurden, teils vorzüglich, insofern allgemeine gegenstände nach diesen Gedankenbestimmungen betrachtet wurden" (VLM, 1817, ad § 18, p. 24).

${ }^{64} \mathrm{WdL}$, II, p. 11 ss.; ver também, E., 1830, § 84, § 112, § 162 A.

65 Essa, talvez, a motivação para interpretações as mais variadas, mas que, de Rosenkranz a Vittorio Hösle, reduzem a Lógica enquanto Teologia especulativa a uma simples ciência a priori. Veja-se, V. HÖSLE, Hegels System,1, op. cit., p. 61 ss., sobretudo. p. 62, nota 5. Veja-setambém,K. ROSENKRANZ, Wissenschaft der logischen Idee. Erster Theil: Metaphysik. Königsberg: Gebruder Vornträger, 1858, p. 36 ss. 
-a, portanto, perder o significado essencial de Filosofia especulativa - o que é manifestamente contraditório. Uma saída ao que parece necessária e suficiente, pelo menos para o caso em questão, reside no confronto entre os $\S 17$ e 18 da Encyklopädie e os comentários aos $\S 12,17$ e 18 das Vorlesungen de 1817, confronto esse cujo resultado, interpretado à luz da hierarquia indicada nos chamados silogismos da Filosofia, tematizados sucintamente nos parágrafos finais das versões de 1817 e 1830 da Encyklopädie, nos indica de modo perfeitamente claro o alcance especulativo e os limites sistemáticos da concepção hegeliana do Lógico ou do Especulativo puro, assim como da Filosofia especulativa pura; isso, precisamente quando Hegel ele mesmo afirma expressamente, no comentário ao $§ 17$ das Vorlesungen, que, "aqui [nas Vorlesungen de 1817 em particular, mas também em suas outras realizações literárias em geral], porém, a Lógica não será considerada como Ciência absoluta, mas simplesmente como uma ciência pela qual o Universal será determinado [como] separado do Concreto"66. De onde, pela exclusão consciente dos significados de Ciência objetiva e universal real e Teologia especulativa - que apresentam a Lógica como Ciência absoluta - do conjunto de sua realização literária explícita ou pelo menos de seu ensino ${ }^{67}$, mantendo-se apenas o de "ciência pela qual o Universal será determinado [como] separado do Concreto" ou de Ciência universal, subjetiva e primeira, considerando os elementos ou aspectos remanescentes dos outros significados no desenvolvimento da Wissenschaft der Logik na sua estrutura linear ${ }^{68}$, podermos afirmar a necessidade e mesmo a exigência do desenvolvimento dessa última àquelas para a plena consecução da Filosofia especulativa pura.

${ }^{66}$ No original: "Hier aber wird die Logik nicht als absolute Wissenschaft betrachtet, sondern bloss als eine Wissenschaft, wodurch das Allgemeine getrennt von dem Konkreten bestimmt wird" (VLM, 1817, ad § 17, p. 24). Compare-se com: WdL, II, 1816, p. 25 ss., p. 237, p. 252-253.

${ }^{67}$ Mesmo que Hegel tencione fazer esse recorte apenas para as versões nas quais está em jogo mais o ensino da Lógica que o seu desenvolvimento científico efetivo caso em que a única exceção seria a grande Lógica de 1812-1816 e a Doutrina do Ser de 1832 -, pensamos que, do ponto de vista de sua realização literária efetiva, ou, o que é o mesmo, do ponto de vista de seu desenvolvimento discursivo e, por conseguinte, de sua estrutura linear, inclusive a grande Lógica permanece submetida ao referido recorte.

${ }^{68}$ Veja-se, entre outros lugares: WdL, I, 1, 1812, p. 8, p.28; WdL, II, 1816, p. 3637, p. 155 ss., p. 160 ss., p. 174-175 ss.,p. 178-179 ss., p. 198, p. 235 ss., p. 253; WdL, I, 1, 1832, p. 8, p. 41-42, p. 207. 
Prova disso é o fato de, na Doutrina do Conceito, Hegel referir-se ao terceiro momento da Idéia, portanto à Idéia absoluta, como "o espírito [que] reconhece a Idéia como sua verdade absoluta, como a verdade que é em si e para si; a Idéia infinita na qual conhecer e agir se conciliaram (sich ausgeglichen hat) e que é o Saber absoluto de si mesma"69. Ora, em vista do que foi dito mais acima e da palavra mesma de Hegel, se nos ativermos às passagens da grande Lógica e da Lógica da Encyklopädie, em suas diversas versões, onde o autor faz alusões ao significado da Lógica como Ciência objetiva e universal real, última ou absoluta e a distingue da Lógica como Ciência subjetiva, universal formal, primeira ou na qual "o Universal será determinado [como] separado do Concreto", aquela determinação teria que pertencer a este segundo significado e não ao primeiro. Mas, com isso, novos problemas se impõem; por exemplo, do ponto de vista hermenêutico, ao se pressupor o chamado Sistema de Hegel no âmbito de uma "unidade sem falhas"70, a hipótese interpretativa segundo a qual se não seria o caso, então, de apenas se operar uma mudança no modo de se ler o Sistema em geral e, nele, a Lógica em especial, como parece fazer crer os diversos estudos existentes - entre outros - sobre a Doutrina dos três silogismos finais ${ }^{71}$ das versões de 1817 e 1830 da Encyklopädie? Outro problema, esse de cunho teorético, é o resultante da constatação do que se tem formulado sob a pergunta em torno do que é vivo e do que é morto na Filosofia de Hegel ${ }^{72}$ ou, o que é o mesmo, da constatação que não mais se pode ser hegeliano numa

69 WdL, II, 1816, p. 178.

70 A expressão "unidade sem falhas" designa aqui a interpretação - ainda vigente de P.-J. Labarrière e G. Jarczyk; a saber, apropriando-nos da explicitação de Pierre Livet, aquela "leitura interna que desenvolve a sistematicidade da dialética e tenta identificar-se ao movimento da manifestação do pensamento de Hegel segundo sua coerência e sua unidade sem falha" (PIERRE LIVET, Réflexivités et extériorité dans la logique de Hegel, in: Archives de Philosophie47, 1984, p. 33-62, aqui, p. 33).

${ }^{71}$ Penso aqui, sobretudo, em: (1) GWENDOLINE JARCZYK, Système et Libertè dans la Logique de Hegel, Paris: Aubier Montaigne, 1980, passim, sobretudo, p. 274 ss.; (2) THÉODORE F. GERAETS, Les trois lectures philosophiques de L'Encyclopédie ou la realisation du concept de la philosophie chez Hegel, in: Hegel-Studien, 10, Bonn: Bouvier, 1975, p. 231-254; (3) B. BOURGEOIS, Présentation. I. L’Encyclopédie des sciences philosophiques. In: G. W. F. HEGEL, Encyclopédie des sciences philosophiques, I. La science de la logique, op. cit., p. 50-55, p. 55-62 [Primeira edição, 1970].

72 Ver, dentre outros, BENEDETTO CROCE, Ciò Che è vivo e cio Che è morto della filosofia di Hegel, Bari: Laterza \& Figli, 1907. Atualmente: HOWARD P. KAINZ, GWF Hegel, The Philosophical System, Ohio: Ohio University Press, 1996, chapter seven: What Is Living and What Is Dead in Hegel Toda? [Disponível on-line, <http:// www.marxists.org/reference/archive/hegel/help/kainz7.htm>, acesso em abril de 2008]. 
época onde o princípio fundamental não é mais o da Subjetividade - e sim o da Intersubjetividade -, cujo estabelecimento não pode mais ser conduzido segundo o procedimento hegeliano como tal, incluindo-se aí também a constatação da discrepância entre a pretensão de Hegel e a sua realização efetiva; o que, de um modo ou de outro, resulta no problema da mediação do Sistema de Hegel - sobretudo a Wissenschaft der Logik - e o pensamento da época atual ${ }^{73}$. Tais problemas, enfim, ao não serem formulados a partir do próprio ponto de vista especulativo, embora partam de diagnósticos importantes sobre o Sistema de Hegel como um todo, terminam por se mostrar opostos e sobretudo unilaterais no que tange ao estatuto próprio da Lógica e do Sistema hegelianos em suas realizações literárias e, para além dessas, quanto ao seu objeto e escopo.

De nossa parte, não corroboramos com a interpretação segundo a qual o Sistema de Hegel se apresenta sob a forma de uma "unidade sem falhas"; na verdade, participamos da tese segundo a qual, em sentido especulativo estrito, levando em conta suas diversas tentativas de realização literária, não há algo como isso que tem sido nomeado o 'Sistema de Hegel'. Do que resulta, no caso em questão, a impossibilidade de uma interpretação consistente do chamado Sistema de Hegel em função justamente dos silogismos da Filosofia tematizados nos parágrafos finais da Encyklopädie de 1817 e da de 1830; o que se prova pelo fato mesmo de na edição de 1827 os tais silogismos não terem sido mobilizados ${ }^{74}$, bem como de nesses silogismos a significação de cada um dos seus termos ou elementos constituintes e das ciências que os consideram mudarem radicalmente, sendo cada qual o que é tão só na unidade e diferença de si consigo mesmo e com seu outro no conjunto das hierarquias que se conformam mediante os referidos silogismos. Ora, na medida em que dispomos de um elenco razoável de significações apenas para a Lógica, e mesmo assim de significações que não foram sistematizadas de modo rigoroso nem mesmo pelo próprio Hegel, que inclusive reconhece as dificuldades intrínsecas a essa tarefa e de certo modo a elas parece haver

73 V. HÖSLE, Hegels System, 1, op. cit., p. 3 ss, p. 52-59, sobretudo, p. 57, nota 77; V. HÖSLE, Die Stellung Hegels Philosophie des objektiven Geistes in seinen System und ihre Aporie, in: Ch. JERMANN (Hg.), Anspruch und Leistung von Hegels Rechtsphilosophie, Stuttgart-Bad Cannstatt: Frommann-Holzboog, 1987, p. 12-13 ss.

74 Ver, a respeito, (1) B. BOURGEOIS, Présentation. III. Le développement de l'esprit. 'In: G. W. F. HEGEL, Encyclopédie des sciences philosophiques, III. Philosophie de l'esprit, op. cit., p. 82-84, nota 34; (2) Th. F. GERAETS, Les trois lectures philosophiques de l'Encyclopédie ou la realisation du concept de la philosophie chez Hegel, in: op. cit., p. 236-240. 
sucumbido, não se pode aqui falar de "unidade sem falhas" ou de uma realização da Idéia da Filosofia segundo as realizações literárias de um suposto Sistema de Hegel. Todavia, não se pode negar a existência ideal - lógico-efetiva -, mas não plenamente realizada em suas distintas versões literárias ou empírico-formais, do Sistema do Lógico em Hegel ${ }^{75}$, do que é a um tempo racional e efetivo, contemplando tanto a parte ideal quanto a parte real da Filosofia; o que significa, do ponto de vista especulativo, que tal Sistema não só permanece atual - no sentido de efetivo, de onde podermos continuar sendo hegelianos - mas também capaz de, em estabelecendo o princípio da Subjetividade absoluta, poder desenvolvê-lo à Intersubjetividade, constituindo-se assim como um Idealismo especulativo da Subjetividade e da Intersubjetividade, provando, portanto, que não há discrepância entre a pretensão de Hegel e a sua realização efetiva, mas tão só a carência de desenvolvimento e sistematização do Lógico ele mesmo - enquanto o conteúdo próprio (ao mesmo tempo ideal e real) de tal Sistema -, sobretudo nas determinações ulteriores à Lógica como Ciência do pensar, de suas determinações e leis em geral no âmbito que Hegel nomeara 'Filosofia especulativa pura'. Para o que, enfim, se exigiria uma consideração do Lógico, segundo a totalidade em movimento de suas configurações, para além do que se convencionou chamar o primeiro silogismo da Filosofia, o Silogismo do Dasein, no qual o Lógico aparece como fundamento e ponto de partida primeiro (no qual a Lógica se apresenta como Ciência primeira, ideal ou universal em face das ciências reais), o que tem lugar no silogismo $\mathrm{L}-\mathrm{N}-\mathrm{E}^{76}$, referente à ordenação linear do Lógico, a Natureza e o Espírito, que é o que conforma a estrutura do chamado Sistema de Hegel tal como ele se deu a conhecer na contingência de suas formas literárias historicamente realizadas ${ }^{77}$.

$75 \mathrm{O}$ que se justifica plenamente se levarmos em conta o que é dito em: E., 1830, §§ 17-18, §§ 84-85, § 145 Ad., § 187 Ad., § 577.

76 E., 1817, § 476; E., 1830, § 575.

77 Por 'formas literárias historicamente realizadas' entendo aqui as três edições da Encyklopädie publicadas pelo próprio Hegel em 1817, 1827 e 1830, nas quais está presente a estrutura linear do Sistema, na qual se ordenam, respectivamente, a Ciência da Lógica, a Filosofia da Natureza e a Filosofia do Espírito, que consideram na sua ordem o Lógico, a Natureza e o Espírito; Sistema esse cujo primeiro esboço data de 1808 e anos seguintes, quando das preleções ginasiais sobre a Enciclopédia filosófica para a classe superior [ver, G. W. F. HEGEL, Enciclopédia para a classe superior (1808 s.). In: G. W. F. HEGEL, Propedêutica filosófica, trad. Artur Morão, Lisboa: Edições 70, 1989, p. 13-84]. Essa Enciclopédia será de ora avante citada conforme o exemplo a seguir: E., 1808, § 14; os outros textos contidos na referida Propedêutica serão citados conforme o modelo em tela, sobretudo as diversas versões da Lógica contidas aí. 
Desse modo, primeiramente, para o significado da Lógica enquanto 'Ciência objetiva e universal real, a sistematização acima aludida teria que desenvolver o chamado Silogismo da Reflexão, o segundo silogismo da Filosofia, no qual o Lógico se mostra como resultado e ponto de chegada, onde a Idéia se apresenta como fundamento último e verdade, silogismo esse no qual a Lógica se nos imporia então como Ciência objetiva e universal real (ou ainda como Ciência do Lógico em si enquanto Real absoluto) e tem lugar no silogismo N - E - L, no qual a ordem necessária seria a Natureza, o Espírito e o Lógico ${ }^{78}$. Desse modo, para o significado da Lógica como Teologia especulativa, a sistematização em jogo teria que desenvolver o Silogismo da Necessidade, o silogismo da Idéia da Filosofia, no qual o Lógico se apresenta como a razão que se sabe, o absolutamente universal, o meio-termo que se cinde em espírito e natureza, o julgar-se pelo qual a Idéia se reparte em espírito e natureza e os determina como Manifestationen da razão que se sabe e o que se reúne nela, a natureza da Coisa ou o que se move para frente e se desenvolve ${ }^{79}$, onde "a Idéia eterna e essente em si e para si, que eternamente se ativa, engendra, e desfruta, como espírito absoluto" 80 ou, o Conceito que se sabe e tem por sua realidade pura e simplesmente os termos que são enquanto momentos do Conceito e é como o Saber universal que, em sua determinidade, permanece imediatamente junto de si mesmoi ${ }^{81}$. De onde, aqui, como já dito anteriormente, a universalidade lógica se apresentar não mais como uma particularidade face à riqueza real, mas contendo-a, apresentando-se como universalidade verdadeira e assim recebendo o significado de Teologia especulativa, tendo lugar no silogismo E - L - N, cuja ordem se constitui pelo Espírito, o Lógico e a Natureza ${ }^{82}$.

Essas indicações confirmam a insuficiência da elaboração levada a cabo por Hegel em torno do Lógico nas diversas realizações literárias da Lógica em especial e do Sistema da Ciência em geral. Se não se trata de uma insuficiência, mas apenas de uma opção de Hegel no que diz respeito à apresentação do Sistema como tal, então ele deveria ter mantido fora de sua elaboração definitiva da Encyclopädie os silogismos finais, tal como fizera em 1827, quando, ao que tudo indica, optara claramente pela redução do Sistema à sua apresentação meramente linear ou, melhor,

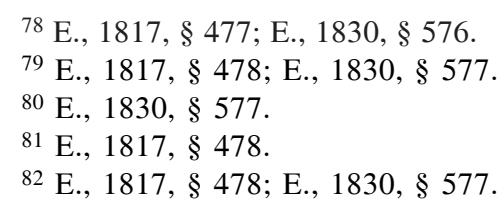


simplesmente segundo o ponto de vista do discurso humano, em última instância, circunscrevendo-se ao Silogismo do Dasein; este que, como percebera dentre outros Lima Vaz, constitui "a primeira e a mais óbvia possibilidade de leitura sistemática do ser em sua totalidade inteligível e, do ponto de vista da condição temporal do discurso humano, a mais fácil de ser seguida"83. Contudo, essa opção resultara numa surpreendente perda de integridade estrutural do projeto hegeliano; justamente porque, ao retirar os silogismos finais da Encyclopädie em 1827, o Sistema deixara como que de dizer respeito ao modo objetivo e ao modo absoluto como as figuras do silogismo articulam e exprimem o processo pelo qual - para além de sua simples consideração subjetiva pelo sujeito filosofante - a própria Razão que se sabe se constitui como tal e se realiza em si e para si mesma. O que, em 1830, mostra-se pelo menos parcialmente corrigido com a reintrodução dos silogismos finais e a referência ao caráter objetivo das figuras do silogismo no adendo ao $\S 187$, completando assim a referência à Idéia já indicada no § 18 da Encyclopädie em 1827 e mantida em 1830.

Que no adendo ao $\S 187 \mathrm{Hegel}$ ele mesmo ou seu transcritor se refira à Idéia lógica e não já à Lógica como "ciência efetivamente universal" como quer Bourgeois ${ }^{84}$ - é algo perfeitamente compreensível e até mesmo algo óbvio segundo o próprio contexto em que tal expressão comparece no referido adendo; além disso, de acordo com o que foi dito até aqui, quanto à ordem linear do discurso humano na Encyclopädie, em sua configuração segundo o silogismo do Dasein, trata-se aí, ainda, apenas da Idéia lógica e não já da Idéia mesma da Filosofia em sua tríplice configuração, não significando esta meramente a apreensão pelo Saber absoluto de seu próprio processo fundador. $\mathrm{O}$ que também não significa que os silogismos finais possam ser pura e simplesmente identificados com essa ou aquela obra de Hegel em especial, mesmo com a Encyclopädie, ou cada uma das ciências enciclopédicas - como quer em geral aqueles que identificam a Idéia indicada no $§ 18$ à Idéia lógica segundo o adendo ao $\S 187$ - em seus três momentos no silogismo absoluto (o conjunto dos três silogismos finais) e à Idéia da Filosofia ou ao terceiro silogismo propriamente dito enquanto silogismo da necessidade ${ }^{85}$. Também não nos parece o caso de aí estar em jogo apenas a possibilidade de leituras justapostas da Encyclopädie, no sentido da

${ }^{83}$ HENRIQUE CLÁUDIO DE LIMA VAZ, Escritos de Filosofia IV. Introdução à Ética filosófica 1. São Paulo: Loyola, 1999, p. 380.

${ }^{84}$ Ver nota do tradutor ao referido adendo, versão Bourgeois, 1979, p. 604.

85 Ver, Th. F. GERAETS, Les trois lectures (...), in: op. cit., p. 231-236. 
realização do conceito da filosofia, tarefa essa cumprida de modo muito satisfatório pelo primeiro silogismo, que é, ele mesmo, a única realização efetiva do projeto hegeliano de uma Filosofia especulativa pura - isto é, seu conceito -, além disso, parece sem sentido fazer repousar toda uma análise e todo o desenvolvimento dos três silogismos na discussão sobre o começo levada a cabo no $§ 17$ da Encyclopädie de 1827 e 1830, ausente em 1817; portanto, do primeiro silogismo enquanto exprimindo a filosofia como pensamento objetivo e o sujeito filosofante como seu espectador passivo, do segundo como dizendo respeito ao próprio ponto de vista do sujeito filosofante e, portanto, ao caráter aberto do pensamento ai em jogo e, enfim, do terceiro silogismo como expressão do processo pelo qual os anteriores se articulam, de modo a realizar assim os três momentos da Idéia: a vida, o conhecer e a Idéia absoluta ${ }^{86}$. Disso se depreende que, (1) se a filosofia, enquanto círculo que retorna dentro de si, não tem começo, sendo este começo apenas uma relação para com o sujeito filosofante, de onde a separação pela qual o pensar é o objeto para um sujeito filosofante (de certo modo exterior), e (2) se o conceito da ciência deve ser apreendido pela ciência mesma, sendo este seu único fim, agir e meta, retornando assim dentro si, então: (a) no que tange ao sujeito filosofante, não temos ainda rigorosamente filosofia especulativa pura (mas apenas sua pressuposição fenomenológica, isto é, a decisão de filosofar que este sujeito leva a cabo), (b) a apreensão do conceito da ciência por ela própria tem que se dar em si e para si, em si e para si mesma, independente do sujeito filosofante como tal (pois o mesmo sabese agora o próprio Eu puro liberado de suas aparências contingentes e das meras faculdades humanas ditas espirituais) e, portanto, sem a oposição entre o sujeito cognoscente e o objeto cognoscível ${ }^{87}$, (c) tal apreensão, embora plenamente realizada - mediante o desenvolvimento enciclopédico fundado no silogismo do Dasein - com o seu retorno dentro de si, ainda não é capaz de se configurar em sua realidade propriamente dita (de acordo com o segundo silogismo), i.é, posta (como a Natureza) e assumida (enquanto o Lógico) por ela mesma como conceito autoconsciente (i.é, como Espírito) e assim, segundo o terceiro silogismo, saber-se a si mesma como Razão que se sabe (o Lógico) em seu conceito autoconsciente (no Espírito) e em sua realidade (na Natureza).

Enfim, as indicações acima aludidas exigem não só que a referida elaboração seja retomada e desenvolvida segundo seu próprio espírito, i.é, para além "do ponto de vista da condição temporal do discurso humano",

86 Ver Th. F. GERAETS, Les trois lectures (...), in: op. cit., p. 236-251 ss.

87 Ver, E., 1830, $§ 20-25$. 
segundo a presença consciente do Lógico, já conquistada mediante as realizações literárias pautadas no primeiro silogismo, ou do espírito ele mesmo no homem, mas ainda que aí se desenvolva o próprio Lógico em si e para si, em si e para si mesmo, ou o Especulativo puro, segundo o ponto de vista e a ciência que lhes são próprios, o ponto de vista especulativo e a Ciência absoluta. O que, contudo, deve ser justificado não só pela capacidade da re-sistematização das diversas determinações do conceito adequado da Lógica e a conseqüente suprassunção das determinações da mesma nesse conceito, mas também pela capacidade de suprassumir as diversas interpretações e tomadas de partido em relação ao System em geral e à Logik Hegels em particular, tomando-as como premissas necessárias, mas não suficientes, para o que nos dias de hoje faz-se preciso realizar.

\section{Para a sistematização do significado mais preciso da Logik}

Partindo então dos três significados principais discutidos mais acima, vamos agora tomar em consideração os seis aspectos - entre os quais aqueles estão incluídos - do que Hegel considera, nas Vorlesungen de 1817, "o significado mais preciso da Lógica", de modo a confrontá-los - em uma próxima oportunidade - com as principais correntes interpretativas e tomadas de posição em torno da Wissenschaft der Logik. Note-se que Hegel é levado a explicitar esse "significado mais preciso da Lógica" em função de sua distinção em relação à Lógica natural (aludida anteriormente), na qual, segundo Hegel, as regras estabelecidas na chamada Theorie für Logik não entram senão aos coices; o que ocorre justamente pelo fato dessa Lógica natural nem sempre seguir tais regras, limitando-se portanto a um sentimento da razão, assim como tão somente às determinações e Formas abstratas, tematizando apenas o ser-aí das Formas-de-pensamento, mas não também a sua verdade ${ }^{88}$. Por isso, de acordo com Hegel ${ }^{89}$, "o significado mais preciso da Lógica" consiste em que ela é:

[1] A ciência do pensar, de suas determinações e leis em geral;

[2] Introdução à filosofia como o fundamento das ciências reais da mesma, como de todas as outras ciências;

88 VLM, 1817 , ad $\S 12$, p. 8.

${ }^{89}$ VLM, 1817, ad $\S 12$, p. 8. 
[3] Não um filosofar exterior à Filosofia, mas parte da mesma, aliás, a parte universal;

[4] Não uma parte, mas a alma imanente e universal e o resultado da ciência completa;

[5] Como ciência da universalidade concreta do Conceito e da Idéia: Ciência especulativa;

[6] Como a ciência especulativa suprema, a Teologia especulativa.

Considerando que os aspectos apresentados em [1], [5] e [6] foram justamente os discutidos mais acima, cabe-nos agora discutir os de número [2], [3] e [4] e a relação de todos os seis aspectos entre si; de modo mais específico, investigar os limites de sua autonomia enquanto tomados cada um por si e a insuficiência de sua posição se isolados uns dos outros. Com base no que foi dito nos parágrafos anteriores, pode-se afirmar agora que apesar de Hegel falar, no $§ 18$ da Encyklopädie de 1817, que "a Logik, no significado essencial de filosofia especulativa, pôs-se na posição do que outrora foi nomeado Metaphysik e tratado como uma ciência separada dela" 90 , esse significado não pode comportar somente a Metafísica, no sentido estrito da Lógica objetiva, ou daquilo que, discutido como o segundo aspecto da Lógica como Filosofia especulativa pura na anotação ao § 17 dessa mesma obra, Hegel chamara "Ciência objetiva e universal real", mas também o primeiro e o terceiro aspecto aí aludidos, a Lógica como Ciência subjetiva e primeira e como Teologia especulativa, isto é, os aspectos [1], [5] e [6] das Vorlesungen. Contudo, enfim, se observarmos com pouco mais atenção também os aspectos [2], [3] e [4] acima elencados, veremos que mesmo eles podem ser verificados na anotação ao $§ 17$ da Encyklopädie de 1817; mas isso, como que ainda indiscernidos entremeio aos significados da Lógica enquanto Ciência subjetiva e primeira (no caso, os aspectos [2] e [3]) e como "Ciência objetiva e universal real" (o aspecto [4]).

Ora, ao lado do aspecto [1], "a ciência do pensar, de suas determinações e leis em geral", mas como que o desdobrando, o aspecto [2], "introdução à filosofia como o fundamento das ciências reais da mesma, como de todas as outras ciências", consiste precipuamente na significação da Lógica como Ciência primeira, ao passo que o aspecto [3], "não um filosofar exterior à Filosofia, mas parte da mesma, aliás, a parte universal", constitui a sua determinação enquanto Ciência universal

${ }^{90}$ No original: "Die Logik, in der wesentlichen Bedeutung speculativer Philosophie, tritt an die Stelle dessen, was sonst Metaphysik gennant und als eine von ihr abgesonderte Wissenschaft abgehandelt wurde" (E., 1817, § 18). 
(formal). Apesar de se apresentarem como distintos entre si, esses três aspectos conformam o significado da Lógica enquanto Ciência subjetiva e primeira, aquele em que, como Filosofia especulativa pura, a Wissenschaft der Logik primeiramente se dá a conhecer, a saber: como a Idéia no Pensar ou o Absoluto ainda encerrado em sua eternidade ${ }^{91}$; isso, em seu significado primeiro e fundamental, e por isso mesmo ainda meramente formal, como que desdobrando os momentos interiores dessa eternidade dentro de si. Ao contrário desses primeiros três aspectos, claramente indicados por Hegel mesmo em vários lugares da pequena Lógica e da grande Lógica ${ }^{92}$, o aspecto [4], "não uma parte, mas a alma imanente e universal e o resultado da ciência completa", e o aspecto [5], "como ciência da universalidade concreta do Conceito e da Idéia: Ciência especulativa", ambos em conjunto, por seu turno, se conformam no significado da Lógica enquanto a Ciência objetiva e universal real, vale dizer, como Ciência última; caso em que a Idéia se apresenta em sua Objetividade perfeita, não mais apenas permanecendo como simples fundamento absoluto do real, mas se mostrando como tal fundamento absoluto no próprio real, perpassando-o assim e nele se perfazendo, na medida mesma em que este, em sua riqueza total, retorna à Idéia pura, pois tem nela seu fundamento último e verdade ${ }^{93}$. De onde, enfim, sob o aspecto de número [6], "como a ciência especulativa suprema", ou, o que é o mesmo, enquanto síntese dos dois significados anteriores, bem como do fundamento absoluto e do fundamento último que neles se exprimem, a Lógica se conformar - ao fim e ao cabo - em sua universalidade verdadeira, no significado de Teologia especulativa ${ }^{94}$.

Conforme o que foi dito anteriormente sobre os significados apresentados na anotação ao $\S 17$ da Encyclopädie de 1817, os seis aspectos do que Hegel chamou "o significado mais preciso da Lógica" podem ser sistematizados, de modo mais rigoroso - e, por isso mesmo, mais adequado - se também os referirmos aos silogismos da Filosofia, apresentados nos parágrafos finais da Encyclopädie de 1817 e 1830. Neste sentido, seguindo o exemplo dos significados apresentados na anotação ao $\S 17$ da Encyclopädie de 1817, e de acordo a sistematização esboçada logo acima, se pode considerar os aspectos elencados por Hegel como que exprimindo - no limite dos três significados principais já discutidos - as

\footnotetext{
91 Ver, WdL,1812, I, 1, p. 21; E., 1817, § 17 A.; WdL, 1832, I, 1, p. 34.

92 Ver, E., 1817, § 12, § 17 A.; E. 1830, § 19, § 114 A., WdL, I, 2, 1813, p. 31 ss; WdL, II, 1816, p. 198.

93 Ver, WdL, II, 1816, p. 198, p. 236; E., 1817, § 17 A.

94 Ver, WdL, II, 1816, p. 178, p. 251; E., 1817, § 17 A.
} 
premissas e a conclusão de cada um dos três silogismos da Filosofia. Assim, o significado da Lógica como Ciência universal, subjetiva e primeira, na medida em que conforma o primeiro silogismo da Filosofia, teria como suas premissas os aspectos [1] e [2] acima elencados, bem como o aspecto [3] como sua conclusão; o mesmo ocorrendo com o significado Ciência objetiva e universal real, ou ainda última, - na medida em que essa conforma o segundo silogismo -, onde o aspecto [4] mostrar-se-ia como as premissas, isso em vista de seu caráter dúplice ou mesmo dissonante [não uma parte, mas, de um lado, (a) a alma imanente e universal e, de outro, (b) o resultado da ciência completa] e o aspecto [5] a conclusão. Por fim, enquanto conformando o terceiro silogismo da Filosofia e já que ele se constitui como a unidade dos significados anteriores, o significado Teologia especulativa teria as conclusões dos silogismos anteriores como suas premissas e o aspecto [6] como sua conclusão.

Mas isso, não obstante, mais que uma interpretação, ou mesmo uma reconstrução ou uma renovação, se configura como uma tentativa de retomada e desenvolvimento do legado hegeliano. Deve-se reconhecer que Hegel ele mesmo não desenvolveu mais que o primeiro significado da Lógica, deixando pois de lado, ou para um momento mais apropriado, o desenvolvimento do segundo e o terceiro significados, perfazendo assim "o significado mais preciso da Lógica"; no entanto, é sabido que nem Hegel ele mesmo nem discípulo algum seu levou a cabo essa tarefa, o mesmo ocorrendo com os chamados silogismos finais da Encyclopädie. Ao contrário disso, a história das interpretações do Sistema de Hegel em geral e da Lógica em especial não mostra senão que seus intérpretes até aqui não fizeram mais que disputar o espólio hegeliano, seja, de um lado, afirmando como que o caráter infalível de tal Sistema, seja, de outro lado, afirmado seu caráter contraditório ou mesmo inconseqüente; o que produziu, de um lado e de outro, dezenas de interpretações e modelos de leitura na maioria das vezes conflitantes entre si. De nossa parte, entretanto, pensamos que essa diversidade de leituras e interpretações ocorre justamente pelo fato de seus proponentes abordarem o Sistema em questão - e as ciências nele consideradas - de um modo meramente subordinado, bem como de justificarem o ponto de vista em que tais leituras e interpretações se baseiam tão somente em um ou outro aspecto ou significado do Sistema em geral e de suas ciências em particular, especialmente da Lógica e da chamada Filosofia real. De onde, enfim, para o que aqui nos interessa, o significado ou o aspecto da Lógica tomado como ponto de partida e fundamento de sua interpretação terminar por determinar a um só tempo tanto a leitura que se faz dessa ciência (e da obra que a exprime) quanto da Filosofia real no que diz respeito ao 
tipo de relação que essa mantém ou deve manter com a primeira. Caso em que, finalmente, ao invés de uma iluminação do problema que realmente está em jogo no Sistema de Hegel, seus intérpretes, pelo fato de geralmente apenas se apropriarem de tal ou tal conceito, segundo tal ou tal significado ou aspecto, terminarem por tomar partido de tal ou tal ponto de vista como característico do Sistema em geral ou de uma sua ciência determinada em particular, privilegiando ora os acertos de Hegel ora seus desacertos. 